\title{
Glucose Phosphate Isomerase Deficiency with Congenital Nonspherocytic Hemolytic Anemia: A New Variant (Type Nordhorn) I. Glinical and Genetic Studies
}

\author{
W. Sahröter, ${ }^{[32]}$ H. H. Koch, B. Wonneberger, and W. Kalinowsky \\ Department of Pediatrics, University of Hamburg, Hamburg
}

A. Arnold and K. G. Blume

Department of Internal Medicine, University of Freiburg, Freiburg im Breisgau

W. HüTHER

Department of Pediatrics, General Hospital Nordhorn, Nordhorn, West Germany

\section{Extract}

A new variant of glucose phosphate isomerase (GPI) deficiency (type Nordhorn) associated with congenital nonspherocytic hemolytic anemia is described. The propositus, an 18-month-old boy of German origin, has suffered since birth from a severe to moderate macrocytic anemia, which is characterized by low mean corpuscular hemoglobin concentration $(28 \%)$, high reticulocytosis (45-60\%), normal osmotic fragility, type $I$ autohemolysis, and short erythrocyte life-span $\left({ }^{51} \mathrm{Cr}_{\mathrm{t}_{1 / 2}}=2\right.$ days). With the exception of GPI, the activities of most erythrocyte enzymes are increased. GPI activity is decreased to $22 \%$ of the normal. The father and mother exhibit GPI activities between $36 \%$ and $47 \%$ of normal. No difference is demonstrable between the enzyme of the propositus and normal subjects concerning Michaelis-Menten constant for fructose 6-phosphate, $\mathrm{pH}$ optimum, and thermal optimum. The stability of the enzyme is decreased in the propositus and in all affected maternal relatives. The enzyme of the paternal relatives is stable. On starch-gel electrophoresis the enzyme of the father is normal (three bands). In the hemolysate of the mother a fourth cathodally migrating band is demonstrable in addition to the three normal bands. The propositus exhibits only one band with a cathodal mobility of $132 \%$ of the main band of normal subjects. It is suggested that the propositus is double heterozygous for two abnormal alleles. The heterozygote mother contributes an allele which produces a thermolabile enzyme of decreased activity and abnormal electrophoretic mobility, whereas the father contributes an allele without enzymatic activity.

The enzyme defect is also manifest in the leukocytes of the propositus (39\% of normal activity). The thermolability is evident in the leukolysates of the propositus and in those of his mother.

When erythrocyte glucose consumption and lactate formation are compared with nonenzymopenic, reticulocyte-rich blood, which has no metabolic defect, the rate of glycolysis is markedly impaired in the propositus. Glucose 6-phosphate, the substrate 
before the defect, accumulates fourfold and probably inhibits hexokinase, and consequently glycolysis. Compared with erythrocyte populations of similar mean cell age, the concentrations of ATP and 2,3-diphosphoglycerate are decreased. After separation of young from old cells the defect becomes more evident in the older population. Premature inactivation of the enzyme during maturation is suggested.

\section{Speculation}

Many so-called "homozygous states" of inherited enzyme defects could be double heterozygous as well. Double heterozygosity may partially explain the clinical heterogeneity of the "homozygous" manifestation, and the lack of correlation between residual enzyme activity and clinical expression in many inborn errors of metabolism. In double heterozygotes with glucose phosphate isomerase deficiency, a premature inactivation of the enzyme during maturation of the erythrocytes may be the reason for metabolic impairment of the cells, followed by premature hemolysis.

\section{Introduction}

Glucose phosphate isomerase (D-glucose-6-phosphateketol-isomerase EC. 5.3.1.9) deficiency, in addition to glucose 6-phosphate dehydrogenase deficiency and pyruvate kinase deficiency, seems to be one of the more common erythrocyte enzyme defects associated with hemolytic anemia. Since the first description in 1967 [4], 12 cases from nine families have been published $[1,5,6,9,12,14,16,21,22]$. Hematologic and biochemical studies reveal many differences in the clinical expression and in the properties of the mutant enzymes. In this paper we describe a new variant of GPI deficiency with congenital nonspherocytic hemolytic anemia. According to the birthplace of the propositus, the variant is designated "Nordhorn."

\section{Case Report}

$M B$, a male of German origin, was born at term as the first child of apparently healthy parents after an uneventful pregnancy. There was no consanguinity in the family. The patient, his father, and his mother were all Rh positive. The hemoglobin concentration was reduced to $10.4 \mathrm{~g} / 100 \mathrm{ml}$ on the 1 st day of life and decreased during the following days. Reticulocyte count was $22 \%$. Serum bilirubin concentration reached its maximum of $6.1 \mathrm{mg} / 100 \mathrm{ml} 8 \mathrm{hr}$ after birth and decreased spontaneously to $1.0 \mathrm{mg} / 100 \mathrm{ml}$ on the 5 th day of life. There was no evidence for fetomaternal incompatibilities. At the age of 2 weeks the patient had rhinitis. Since hemoglobin was only $5.1 \mathrm{~g} / 100 \mathrm{ml}$, a first blood transfusion was necessary, followed by two other transfusions during the following year on the occasion of hemolytic crisis when the propositus again had infections of the respiratory tract. GPI deficiency was diagnosed at the age of 5 months.

\section{Materials and Methods}

Routine hematologic studies were performed by standard methods [10]. Autohemolysis was determined after the addition of preservative-free heparin according to the method of Selwyn and Dacie [24] in the modification of the method of Young et al. [27]. Hemoglobin electrophoresis was performed on cellulose acetate strips [26].

Erythrocytes were obtained from heparinized blood samples from the propositus, his relatives, normal control subjects, and five patients with moderate reticulocytosis, two of them suffering from autoimmune hemolytic anemia, and three from hemolytic anemia of unknown origin.

Erythrocyte enzymes were assayed at $37^{\circ}$ in hemolysates prepared with digitonin [29]. Leukocytes were carefully separated by filtration through a cotton wool column [8]. The final erythrocyte suspensions contained less than 50 leukocytes $/ 10^{6}$ erythrocytes. The GPI activity was assayed at its $\mathrm{pH}$ optimum by a modification of the procedure described by Koutras et al. [13], using $0.05 \mathrm{~m}$ Tris-HCl buffer, $\mathrm{pH}$ 8.2. Enzyme units are expressed as micromoles of NADPH generated per minute per gram of hemoglobin. The assay procedures for all other erythrocyte enzymes were reported in a previous study [20].

Leukocytes were separated according to the method of Böyum [7]. The suspensions contained 1.4 erythrocytes/leukocyte. After threefold resuspension of the cells in water, the erythrocyte contamination was re- 
Table $I$. Autohemolysis studies on erythrocytes

\begin{tabular}{lcccc}
\hline & \multicolumn{4}{c}{ Hemolysis, \% } \\
\cline { 2 - 5 } \multicolumn{1}{c}{ Subject } & \multicolumn{4}{c}{ Additive } \\
\cline { 2 - 5 } & None & $\begin{array}{c}0.025 \mathrm{M} \\
\text { Glucose }\end{array}$ & $\begin{array}{c}0.005 \mathrm{M} \\
\text { ATP }\end{array}$ & $\begin{array}{c}0.005 \mathrm{M} \\
\text { Adenosine }\end{array}$ \\
\hline $\begin{array}{l}\text { Normal control } \\
\text { subjects (n }=\end{array}$ & $0.2-2.0$ & $0.1-1.0$ & $0.1-1.0$ & $0.1-1.0$ \\
$\quad 20)$ & & & & \\
Propositus & 7.1 & 6.0 & 2.3 & 3.0 \\
$\begin{array}{l}\text { Father } \\
\text { Mother }\end{array}$ & 0.9 & 0.4 & 0.6 & 0.4 \\
& 0.7 & 0.4 & 0.5 & 0.4 \\
\hline
\end{tabular}

duced to 0.7 erythrocyte/leukocyte. Each assay was calculated on the basis of erythrocyte and leukocyte counts performed simultaneously. The leukocytes were lysed by threefold freezing and thawing [3]. Leukocyte GPI activity was expressed as micromoles of NADPH generated per minute per $10^{9}$ leukocytes.

Michaelis-Menten constants $\left(\mathrm{K}_{\mathrm{m}}\right)$ of GPI for fructose 6-phosphate (F6P) were determined at $\mathrm{pH} 8.2(0.05 \mathrm{M}$ Tris-HCl buffer) for 12 concentrations of F6P, which varied between 0.005 and $1.0 \mathrm{~mm}$. Thermal stability of GPI was studied in hemolysates which were prepared with digitonin, water, and $0.05 \mathrm{M}$ Tris- $\mathrm{HCl}$ buffer, $\mathrm{pH}$ 8.2, which gave final hemoglobin concentrations of $10-15 \mathrm{mg} / \mathrm{ml}$, and in lysates of leukocytes. The thermal optimum of GPI activity was determined in the standard assay at various temperatures. The GPI electrophoresis was carried out using the technique of Detter et al. [11] with Tris-citric acid buffer [30]. Glycolytic metabolites, glucose consumption, and lactate formation were measured using methods reported previously [20].

Erythrocytes were fractionated in younger and older cells by differential centrifugation [15] using glutamate oxalacetate transaminase activity as an indicator of cell age [18].

\section{Results}

\section{Hematologic Data}

At the time of study the patient displayed a moderate macrocytic hemolytic anemia (mean corpuscular volume $119 \mathrm{fl}$ ) with a hemoglobin concentration of 8.5 $\mathrm{g} / 100 \mathrm{ml}$, a packed cell volume of $30.5 \%$, and a reticulocytosis of $45-60 \%$. The mean corpuscular hemoglobin concentration was decreased to $28 \%$. Peripheral blood smears showed moderate polychromasia, anisopoikilocytosis, erythroblasts, and to some extent, hypochromasia. Leukocyte and platelet counts were within the normal range. Haptoglobin could not be demonstrated. The half-life $\left({ }^{51} \mathrm{Cr} \mathrm{t}_{1 / 2}\right)$ of the autotransfused erythrocytes of the patient was 2 days. Erythrocyte sequestration was not greater in the moderately enlarged spleen than in the liver. The bilirubin concentration was increased to $10.2 \mathrm{mg} / 100 \mathrm{ml}$ serum; $9.7 \mathrm{mg} / 100 \mathrm{ml}$ were in the unconjugated form. Iron concentration of the serum was $107 \mu \mathrm{g} / 100 \mathrm{ml}$. The antiglobulin test was negative, and no abnormal hemoglobin could be demonstrated by electrophoresis. Fetal hemoglobin was slightly increased to $3.3 \%$. The osmotic fragility of fresh blood was in the normal range. There was no significant change after a 24-hr incubation at $37^{\circ}$. All of the other family members had normal hematologic studies.

\section{Autohemolysis}

Autohemolysis was moderately increased in the patient and partially corrected by the addition of glucose, ATP, and adenosine (Table I). This pattern is most consistent with type I autohemolysis as classified by Selwyn and Dacie [24]. The parents showed a normal autohemolysis pattern.

\section{Erythrocyte Enzymes}

The activities of the following enzymes were assayed: hexokinase, phosphoglucomutase, GPI, phosphofructokinase, fructose diphosphate aldolase, glyceraldehyde 3-phosphate dehydrogenase, triosephosphate isomerase, 2,3-diphosphoglycerate mutase, 3-phosphoglycerate kinase, 3-phosphoglycerate mutase, enolase, pyruvate kinase, glucose 6-phosphate dehydrogenase, 6-phosphogluconic dehydrogenase, and glutathione reductase. With the exception of GPI, all of the activities were increased or normal in the propositus in a pattern usually found in young erythrocyte populations in hemolytic anemias.

\section{Erythrocyte GPI}

In the propositus GPI activity was decreased to $22 \%$ of normal, even in the presence of a reticulocyte count of $45 \%$ (Table II). His father and his mother and five other relatives exhibited GPI activities between $36 \%$ and $47 \%$ of normal.

Some properties of GPI are shown in Table III. Using hemolysates, the Michaelis-Menten constants for F6P and the $\mathrm{pH}$ optimum of the patient's enzyme were within the ranges for normal individuals. Striking differences between the enzyme of the patient and his maternal relatives with reduced activity on the one hand, and his paternal relatives with reduced activities and normal individuals on the other, are shown in 
Figure 1. Whereas the enzyme of the patient and of his maternal relatives was unstable at $45^{\circ}$, the enzyme of the afflicted paternal relatives was stable. The instability of the enzyme also became evident when whole blood of the propositus and of his mother was incubated at $45^{\circ}$. No change in the temperature optimum of the patient's enzyme was demonstrable (Fig. 2).

On starch-gel electrophoresis (Fig. 3), only one fast cathodic band of GPI activity with a mobility of $132 \%$ of the main band of normal subjects was demonstrable. The father showed a normal pattern, whereas the mother exhibited an additional band which migrated faster to the cathode than the main band of normal subjects, but slower than the patient's band.

\section{Erythrocyte Metabolic Studies}

The concentrations of some glycolytic intermediates are shown in Table III. The most prominent finding

Table II. Erythrocyte glucose phosphate isomerase (GPI) activity ${ }^{1}$

\begin{tabular}{ll}
\hline \multicolumn{1}{c}{ Subject } & GPI activity \\
\hline Normal (mean $\pm 2 \mathrm{sD}$ ) & $87.7 \pm 9.2$ \\
Propositus, IIIa & $18.8^{2}$ \\
Father, IIa & 31.8 \\
Mother, IIb & 32.8 \\
Maternal aunt, IIc & 36.7 \\
Maternal uncle, IId & 32.6 \\
Maternal uncle, $I I e$ & 63.5 \\
Maternal aunt, IIf & 41.4 \\
Paternal grandfather, Ia & 63.7 \\
Paternal grandmother, $I b$ & 32.8 \\
Maternal grandfather, $I c$ & 34.1 \\
Maternal grandmother, $I d$ & 70.2 \\
\hline
\end{tabular}

${ }^{1}$ Micromoles of NADPH generated per minute per gram of hemoglobin.

${ }^{2}$ Mean of four determinations.

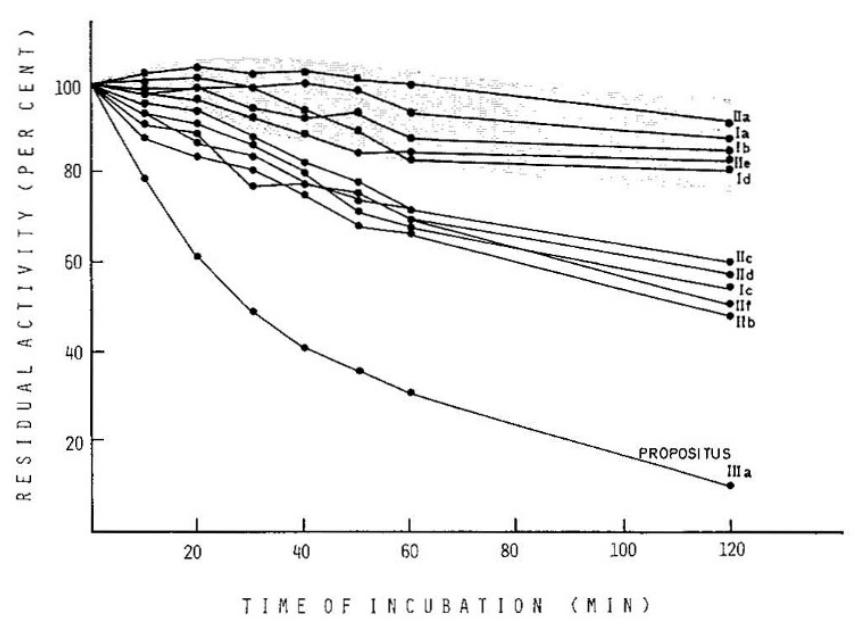

Fig. 1. Stability of erythrocyte glucose phosphate isomerase (GPI). The hemolysates, prepared with Tris-HCl buffer, $\mathrm{pH} 8.2$, were incubated at $45^{\circ}$. At definite intervals aliquots were removed and assayed for GPI activity. Genealogic designation was according to Fig. 5 .

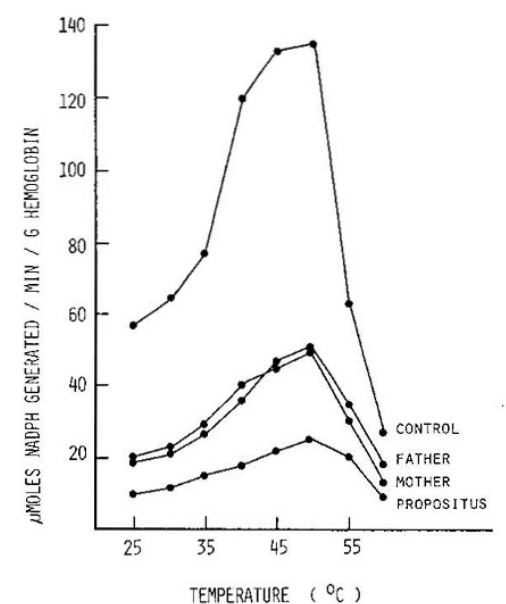

Fig. 2. Erythrocyte glucose phosphate isomerase activity at different temperatures.

Table III. Properties of erythrocyte glucose phosphate isomerase (GPI) and glycolytic metabolites

\begin{tabular}{|c|c|c|c|c|c|}
\hline Property & Normal & Moderate reticulocytosis & Propositus & Father & Mother \\
\hline Reticulocytes, $\%$ & $<0.15$ & $20-35.2$ & 45 & 0.8 & 1.0 \\
\hline GPI activity ${ }^{1}$ & $87 \pm 9.2^{2}$ & $117.0^{3}$ & 18.8 & 31.8 & 32.8 \\
\hline $\begin{array}{c}\mathrm{K}_{\mathrm{m}} \text { (fructose } 6 \text {-phos- } \\
\text { phate) } \times 10^{-5} \mathrm{M}\end{array}$ & $6.5 \pm 1.3^{2}$ & $6.8^{3}$ & 5.8 & 5.2 & 5.9 \\
\hline $\mathrm{pH}$ optimum & $8.2-8.4$ & $8.2-8.5$ & 8.2 & 8.4 & 8.5 \\
\hline \multicolumn{6}{|l|}{ Glycolytic metabolites ${ }^{4}$} \\
\hline Glucose 6-phosphate & $0.24 \pm 0.04^{2}$ & $0.35^{3}$ & 1.3 & 0.2 & 0.3 \\
\hline ATP & $13.5 \pm 2.5^{2}$ & $16.5^{3}$ & 11.8 & 12.4 & 12.2 \\
\hline 2,3-Diphosphoglycerate & $46.0 \pm 6.2^{2}$ & $56.4^{3}$ & 44.8 & 48.3 & 52.1 \\
\hline
\end{tabular}

${ }^{1}$ Micromoles of NADPH generated per minute per gram of hemoglobin.

${ }^{2}$ Mean \pm 2 sD.

${ }^{3}$ Mean of five patients with nonenzymopenic hemolytic anemia.

${ }^{4}$ Micromoles per $10 \mathrm{ml}$ packed erythrocytes. 


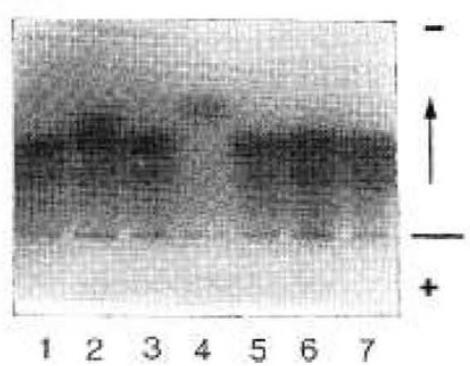

Fig. 3. Starch-gel electrophoresis of erythrocyte glucose phosphate isomerase. Channels 1, 3, 5, and 7: hemolysates of normal control subjects; channel 2: mother; channel 4: propositus; channel 6: father. consumption was $62 \%$ and lactate formation $59 \%$ higher than the mean value of normal blood. However, when compared with reticulocyte-rich blood, the glycolytic rate of the erythrocytes of the patient was significantly reduced. In spite of the high reticulocyte count, the utilization of glucose was only $69 \%$, and the formation of lactate only $67 \%$ of the rates expected from blood with reticulocyte counts between $20 \%$ and $35.5 \%$.

\section{Comparison of Younger and Older Erythrocytes}

After sedimentation at $30,000 \times g$, the top $10 \%$ fraction and the bottom $10 \%$ fraction of the erythrocytes

Table IV. Comparison of whole erythrocyte population with younger (top 10\% fraction) and older (bottom 10\% fraction) erythrocytes from the propositus

\begin{tabular}{|c|c|c|c|c|c|}
\hline \multirow[b]{2}{*}{ Property } & \multirow[b]{2}{*}{ Normal } & \multirow{2}{*}{$\begin{array}{l}\text { Moderate reticulocytosis } \\
\qquad(n=5)\end{array}$} & \multicolumn{3}{|c|}{ Propositus } \\
\hline & & & $\begin{array}{l}\text { Whole erythrocyte } \\
\text { population }\end{array}$ & Top fraction & Bottom fraction \\
\hline Reticulocytes, $\%$ & 1.5 & $20-35.5$ & 45.0 & 73.5 & 20.2 \\
\hline GOT activity ${ }^{1}$ & $3.6 \pm 0.6^{2}$ & $7.4^{3}$ & 6.9 & 7.9 & 1.7 \\
\hline GPI activity ${ }^{1}$ & $87.7 \pm 9.2^{2}$ & $117.0^{3}$ & 18.8 & 18.2 & 8.5 \\
\hline $\begin{array}{l}\text { GPI } \mathrm{K}_{\mathrm{m}} \text { (fructose } 6 \text {-phos- } \\
\text { phate })\left(\times 10^{-5} \mathrm{M}\right)\end{array}$ & $6.5 \pm 1.3^{2}$ & $6.8^{3}$ & 5.8 & 6.2 & 5.5 \\
\hline Glucose consumption ${ }^{4}$ & $19.1 \pm 2.4^{2}$ & $45.2^{3}$ & 31.0 & 39.6 & 29.5 \\
\hline Lactate formation ${ }^{4}$ & $37.1 \pm 3.9^{2}$ & $85.5^{3}$ & 59.2 & 76.6 & 60.6 \\
\hline
\end{tabular}

${ }^{1}$ Micromoles of substrate utilized per minute per gram of hemoglobin. GOT: glutamate oxalacetate transaminase; GPI: glucose phosphate isomerase.

${ }^{2}$ Mean \pm 2 sD.

${ }^{3}$ Mean of five patients with hemolytic anemia, but without any enzyme defect.

${ }^{4}$ Micromoles utilized or formed per hour per $10 \mathrm{ml}$ packed cells.

Table $V$. Activity and Michaelis-Menten constant of glucose phosphate isomerase (GPI) from leukocytes

\begin{tabular}{lcc}
\hline \multicolumn{1}{c}{ Subject } & GPI activity & $\begin{array}{c}\mathrm{K}_{\mathrm{m}} \text { (fructose } \\
\text { 6-phosphate) }\end{array}$ \\
\hline Normal (mean $\pm 2 \mathrm{SD})(\mathrm{n}=5)$ & $145 \pm 35$ & $5.8 \pm 1.5$ \\
Propositus & 56 & 7.5 \\
Father & 137 & 7.6 \\
Mother & 123 & 6.0 \\
\hline
\end{tabular}

${ }^{1}$ Micromoles of NADPH generated per minute per $10^{9}$ leukocytes.

${ }^{2} \times 10^{-5} \mathrm{M}$.

was the fourfold elevation of glucose 6-phosphate, accumulating before the enzyme block, in the erythrocytes of the patient when compared with patients with moderate reticulocytosis. On the other hand, the concentrations of ATP and 2,3-diphosphoglycerate were lower than expected from the reticulocyte count of the erythrocyte population.

The rate of glycolysis is shown in Table IV. In the whole erythrocyte population of the propositus, glucose of the patient were compared (Table IV). Because of the relatively high reticulocyte count of the whole population, it was impossible to yield a bottom fraction free of reticulocytes. Nevertheless, the finding of only $45 \%$ GPI activity in the bottom fraction indicates an inactivation of the enzyme in the older cells resulting in a decreased glycolytic rate (Table IV). There was no difference between the top and the bottom fraction regarding the stability at $45^{\circ}$, the temperature optimum, the Michaelis-Menten constant for F6P, and the pH optimum of GPI.

\section{Leukocyte GPI}

In the propositus, leukocyte GPI activity was decreased to 56 units, i.e. $39 \%$ of the normal mean (Table V). The activities of both parents were within the normal range. The Michaelis-Menten constant of the mutant enzyme is normal. In contrast, striking differences were observed in the thermal stability at $45^{\circ}$. As in erythrocytes, the leukocyte enzyme of the propositus 
and of his mother was highly unstable, whereas the leukocyte enzyme of the father was stable (Fig. 4).

\section{Discussion}

The propositus suffers from a hereditary hemolytic anemia associated with an inborn error of erythrocyte metabolism, GPI deficiency. The anemia is characterized by the well known signs of nonspherocytic hemolytic anemia: macrocytosis, anisopoikilocytosis, polychromasia, reticulocytosis, hyperbilirubinemia, and normal osmotic fragility. A remarkably low mean corpuscular hemoglobin concentration has also been observed in most $[5,6,12]$, but not in all cases of GPI deficiency $(1,6,22)$. The autohemolysis corresponds to type $I$, as originally categorized by Selwyn and Dacie [24]. The same pattern has been observed in hemolytic anemias with other metabolic defects in early stages of erythrocyte glucose metabolism [22].

The metabolic defect of the propositus is substantiated by direct measurement of the markedly reduced erythrocyte GPI activity, both when compared with normal erythrocyte populations and when compared with reticulocyte-rich blood. The demonstration of intermediate enzyme activities in both parents and in five other family members suggests an autosomal recessive mode of inheritance (Fig. 5). In regard to the Michaelis-Menten constants for F6P, the $\mathrm{pH}$ optimum, and the temperature optimum, no difference could be demonstrated between the enzyme of the propositus, his parents and his relatives on the one hand, and normal individuals on the other. However, the enzyme demonstrates distinct pattern of thermal stability and electrophoretic migration within the affected family members. The enzyme of the propositus and of the heterozygous maternal relatives is unstable at $45^{\circ}$, whereas the enzyme of the heterozygous paternal relatives is stable. Electrophoretically, the enzyme of the father does not differ from the normal enzyme, but that of the mother shows a fourth band which migrates faster to the cathode. The single band of the propositus is not identical with the fourth band of his mother.

These results can be interpreted as follows. Inasmuch as GPI seems to be a dimer of two subunits, there is no reason to expect that the propositus has inherited the same abnormal allele from both parents, especially because the parents are not related. The patient's residual enzyme is unstable and behaves electrophoretically abnormally. It is most likely that the mother contributed an allele which produces a thermolabile enzyme of decreased activity, whereas the father

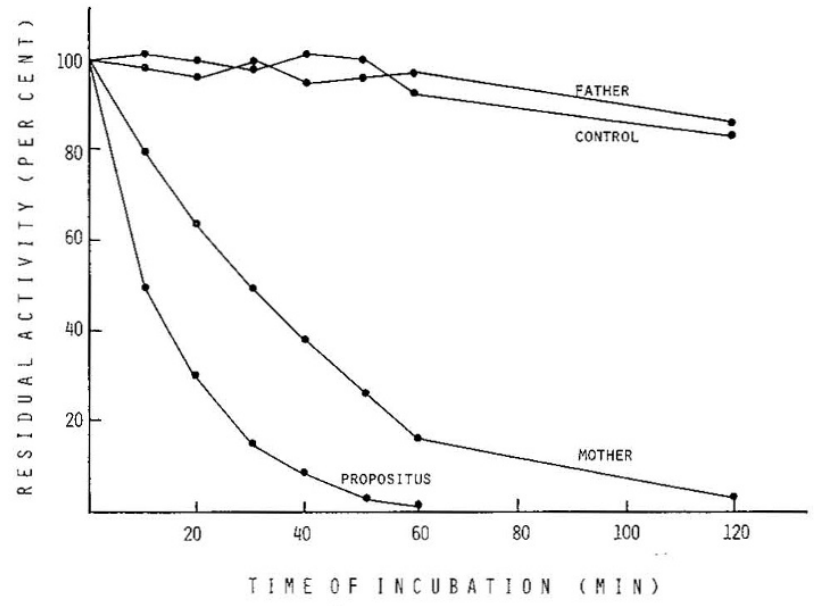

Fig. 4. Stability of leukocyte glucose phosphate isomerase (GPI). Lysates of lcukocytes, prepared with $0.05 \mathrm{M}$ Tris- $\mathrm{HCl}$ buffer, $\mathrm{pH}$ 8.2 , were incubated at $45^{\circ}$. At definite intervals aliquots were removed and assayed for GPI activity.

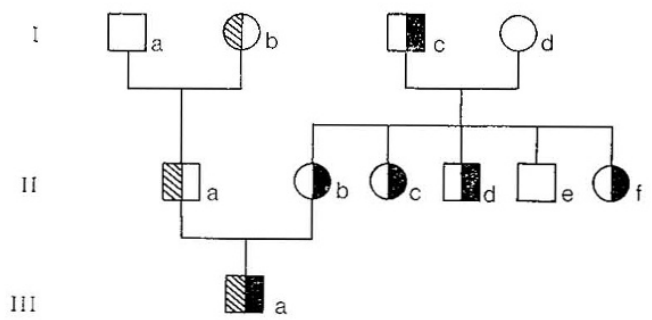

Fig. 5. Pedigree of family $B$ with glucose phosphate isomerase (GPI) deficiency. : heterozygote for GPI-Nordhorn (decreased activity, thermal instability, abnormal electrophoretic mobility); V/A: hetcrozygote for GPI (-) (decreased activity, normal stability, normal electrophoretic mobility).

contributed an allele without activity. The normal electrophoretic mobility of the father's residual enzyme suggests that his abnormal allele codes for a virtually inactive enzyme. The deficient allele in the mother codes for the electrophoretically fast moving enzyme with decreased stability and decreased activity. Therefore, the propositus is not "homozygous" but "double heterozygous" for two abnormal genes, a fact which has been described for GPI-Los Angeles [6] and for the first case of GPI deficiency published by Baughan et al. [5], and possibly for many other clinical syndromes associated with genetically determined enzyme defects. Double heterozygosity may also partly explain the clinical heterogeneity of many so-called "homozygous" states of inherited enzyme defects [17] and the lack of correlation between residual enzyme activity and severity of the clinical manifestation.

The fast electrophoretic mobility clearly distin- 
guishes GPI-Nordhorn from all the other genetic variants with normal GPI activity [11], and also from all variants with decreased activity $[1,4,5,6,12,14,16$, 22].

In the presented case, the activity of GPI is also decreased in the leukocytes of this patient, but is normal in his parents. Although this is true for all cases of GPI deficiency, there are individual differences in the residual activity. Furthermore, a low thermal stability in the leukocytes of the propositus and of his mother could be demonstrated. A generalized deficiency of GPI may be conceivable present in the propositus, as it is in triosephosphate isomerase deficiency [19], but there is no evidence that the mutant enzyme is clinically important in other cells than the erythrocytes.

As in most inherited erythrocyte enzyme defects, the question of why the erythrocytes do not survive normally remains open. Beyond all doubt, the erythrocytes of the propositus are metabolically disturbed. Although they consume more glucose and form more lactate than normal erythrocyte populations with low reticulocyte counts, the metabolic impairment becomes evident when the rate of glycolysis is compared with that of reticulocyte-rich blood. The significant reduction of glycolysis may be caused partially by the accumulation of glucose 6-phosphate, which inhibits the rate-limiting enzyme of glycolysis, hexokinase. Consequently, low levels of the substrates below the GPI reaction, especially ATP and 2,3-diphosphoglycerate, are found. Thus, the short life-span of the erythrocytes of the propositus may be due to their low glycolytic rate. Moreover, after fractionation, a much more reduced GPI activity and glycolytic rate could be demonstrated in the older as compared with the younger cells. This suggests that GPI activity decreases faster than the activities of the other erythrocyte enzymes, possibly because of their instability, and becomes crucial and fatal as cells mature [2]. On the other hand, Baughan et al. [5] and Paglia et al. [16] have shown that recycling of carbon-2-labeled glucose through the oxidative hexosemonophosphate shunt is far below normal in patients with GPI deficiency. Because the complete metabolic capacity of the reticulocyte depends mainly on the oxidative shunt [23], it may be assumed that in GPI deficiency the viability of the reticulocytes may be additionally impaired.

\section{Summary}

A new variant of glucose phosphate isomerase deficiency (type Nordhorn) associated with congenital nonspherocytic hemolytic anemia is described. The propositus is double heterozygous for two abnormal alleles. The heterozygous mother contributes an allele coding for a thermolabile enzyme with decreased activity and abnormal electrophoretic mobility, whereas the father contributes an inactive gene product. The enzyme defect becomes also manifest in the leukocytes of the propositus. The enzyme of maternal leukocytes exhibits a decreased thermal stability.

\section{References and Notes}

1. Arnold, H., Blume, K. G., Busch, D., Lenkeit, U., Löhr, G. W., AND LüBS, E.: Klinische und biochemische Untersuchungen zur Glucosephosphatisomerase normaler menschlicher Erythrozyten und bei Glucosephosphatisomerase-Mangel. Klin. Wschr., f8: 1299 (1970).

2. Arnold, H., Blume, K. G., Engelhariot, R., and Löhr, G. W.: Glucose-phosphate isomerase deficiency: Evidence for in vivo instability of an enzyme variant with hemolysis. Blood, $t 1$ : 69] (1973).

3. Barthelmai, W., Vetrella, M., Eschenbach, C., and Jehn, E.: Leukocytenisolierung aus kleinen Blutvolumina. Klin. Wschr., f9: 263 (197I).

4. Baughan, M. A., Valentine, W. N., Paglia, D. E., Ways, P. O., Simon, E. R., ANd DeMarsh, Q. B.: Hereditary hemolytic anemia associated with glucosephosphate isomerase (GPI) dcficiency: A new enzyme defect of human erythrocytes. Blood, 30: $850(1967)$.

5. Baughan, M. A., Valentine, W. N., Paglia, D. E., Ways, P. O., Simon, E. R., AND DeMarsh, Q. B.: Hereditary hemolytic anemia associated with glucosephosphate isomerase (GPI) deficiency: A new enzyme defect of human erythrocytes. Blood, 32: $236(1968)$.

6. Blume, K. G., Hryniuk, W., Powars, D., Trinidad, F., West, C., AND Beutrer, E.: Characterization of two new variants of glucose-phosphatc-isomerase deficiency with hereditary nonspherocytic hemolytic anemia. J. Lab. Clin. Med., 79: 942 (1972).

7. Börum, A.: Separation of leukocytes from blood and bonc marrow. Scand. J. Clin. Lab. Invest., 21 (suppl. 97): (1968).

8. Busch, D., AND Pelz, K.: Erythrocytenisolierung aus Blut mit Baumwolle. Klin. Wschr., 44: 983 (1966).

9. Cartier, P., Temkine, H., and Griscelli, C.: Etude biochimique d'une anémie hémolytique avec déficit familial en phosphohexisomerase. Enzymol. Biol. Clin. 10: 439 (1969).

10. Chrtwright, G. E.: Diagnostic Laboratory Hematology, Ed. 4 (Grune \& Stratton, New York, 1968).

11. Detter, J. C., Ways, P. O., Giblett, E. R., Baughan, M. A., Hopkinson, D. A., Povey, S., ANd Harris, H.: Inherited variations in human phosphohexose isomerase. Ann. Hum. Genet., 31: 329 (1968).

12. Engelhardt, R., Arnold, H., Hoffman, A., Jacobi, H., and LöHR, G. W.: GPI-Recklinghausen: A new variant of glucosephosphate isomerase deficiency with hemolytic anemia. In: E. Gerlach, K. Moser, E. Deutsch, and W. Wilmanns: Erythrocytes, Thrombocytes, Leukocytes. Recent Advances in Membranc and Metabolic Research, Second International 
Symposium, Vienna, June 1972, p. 180 (Thieme, Stuttgart, 1973).

13. Koutras, G. A., Hattori, M., Schneider, A. S., Ebaugh, F. G., JR., AND Valentine, W. N.: Studies on chromated erythrocytes: Effect of sodium chromate on erythrocyte glutathione reductase. J. Clin. Invest., 43: 323 (1964).

14. OskI, F., AND Fuller, E.: Glucose-phosphate isomerase (GPI) associated with abnormal osmotic fragility and spherocytes. Clin. Res., 19: 427 (1971).

15. Oski, F. A., Naiman, J. L., Blum, S. F., Zarkowsky, H. S., Whaun, J., Shohet, S. B., Green, A., and Nathan, D. G.: Congenital hemolytic anemia with high-sodium, low-potassium red cells. Studies of three generations of a family with a new variant. New Engl. J. Med., 280: 909 (1969).

16. Paglia, D. E., Holland, P., Baughan, M. A., and Valentine, W. N.: Occurrence of defective hexosephosphate isomerization in human erythrocytes and leukocytes. New Engl. J. Med., 280: 66 (1969).

17. Paglia, D. E., Valentine, W. N., Baughan, M. A., Miller, D. R., REed, C. F., AND MCINTYRe, O. R.: An inherited molecular lesion of erythrocyte pyruvate kinase: Identification of a kinetically aberrant isozyme associated with premature hemolysis. J. Clin. Invest., 47: 1929 (1968).

18. Sass, D., Vorsanger, E., ANd Spear, P. W.: Enzyme activity as indicator of cell age. Clin. Chim. Acta, 10: 21 (1964).

19. Schneider, A. S., Valentine, W. N., Baughan, M. A., Paglia, D. E., Shore, N. A., And Heins, H. L., JR.: Triosephosphate isomerase deficiency, a multi-system inherited enzyme disorder. Clinical and genetic aspects. In: E. Beutler: Hereditary Disorders of Erythrocyte Metabolism, p. 265 (Grune \& Stratton, New York, 1968).

20. SCHRÖTER, W.: Transistorischer Pyruvatkinase- und Glutathionreductase-Mangel der Erythrocyten bei chronischer idiopathischer infantiler Pancytopenie. Klin. Wschr., 48: 1407 (1970).

21. Schröter, W., Brittinger, G., Zimmerschitt, E., ANd König, E.: A new hemolytic syndrome with glucosephosphate isomerase (GPI) and glucosc-6-phosphate dehydrogenase (G-6-
PD) deficiency of the erythrocytes: Biochemical studies. Eur. J. Clin. Invest., 1: 145 (1970).

22. Schröter, W., Britringer, G., Zimmerschitt, E., König, E., AND SCHRADER, D.: Combined glucosephosphate isomerase and glucose-6-phosphate dehydrogenase deficiency of the erythrocytes: A new hemolytic syndrome. Brit. J. Haematol., 20: 249 (1971).

23. Schultze, M., Rapoport, S., and Lach, A.: Einfluß von Methylenblau auf die Veratmung von Substraten in Reticulocyten. Fol. Haematol. (Leipzig), 83: 477 (1965).

24. Selwyn, J. G., And Dacie, J. V.: Autohemolysis and other changes resulting from incubation in vitro of red cells from patients with congenital hemolytic anemia. Blood, 9: 414 (1954).

25. Tariverdian, G., Arnold, H., Blume, K. G., Lenkeit, U., And LöHR, G. W.: Zur Formalgenetik der Phosphoglucoseisomerase (EC: 5.3 .1 .9$. ): Untersuchung einer Sippe mit GPI-Defizienz. Humangenetik, 10: 218 (1970).

26. Wehinger, H., And Alebouye, M.: Densitometrisch-quantitative Bestimmung von Hämoglobinen nach Mikrozonen-Elektrophorese auf Cellulose-Acetat-Folie. Klin. Wschr., 48: 701 (1970).

27. Young, L. E., Izzo, M. J., ANd Swisher, S. N.: Studies on spontaneous in vitro autohemolysis in hemolytic disorders. Blood, 11: 977 (1956).

28. The biochemical substrates, coenzymes, and enzymes were products from Boehringer \& Soehne, Mannheim, Germany.

29. Starch for glucose phosphate isomerase electrophoresis was purchased from Electrostarch Company, Madison, Wisconsin.

30. This work was supported by the Deutsche Forschungsgemeinschaft, Bonn-Bad Godesberg, Germany.

31. The present address of W. Schröter, H. H. Koch, B. Wonneberger, and W. Kalinowsky is Department of Pediatrics, University of Göttingen, West Germany.

32. Requests for reprints should be addressed to: WERNER SCHröTER, M.D., Department of Pediatrics, University of Göttingen, D-3400 Göttingen, Humboldt allee 38, West Germany.

33. Accepted for publication September 11, 1973. 